\title{
RAZGLEDI
}

\section{SPREMEMBE POKRITOSTI DNA Z MORSKIMI TRAVNIKI V SEMEDELSKEM ZALIVU V OBDOBJU 2009-2015}

\author{
AVTORICI \\ dr. Mojca Poklar \\ Harpha Sea, d.o. o. Koper, Čevljarska ulica 8, SI - 6000 koper, Slovenija; \\ mojcap@harphasea.si
}

dr. Valentina Brečko Grubar

Univerza na Primorskem, Fakulteta za humanistične študije, Titov trg 5, SI - 6000 koper, Slovenija

valentina.brecko.grubar@fhs.upr.si

DOI: $10.3986 / G V 90204$

UDK: 551.468:581.526.323(497.472)"2009/2015"

COBISS: 1.01

\section{IZVLEČEK}

Spremembe pokritosti dna z morskimi travniki v Semedelskem zalivu v obdobju 2009-2015

Prispevek predstavlja rezultate večletnega preučevanja razširjenosti in spreminjanja površine morskih travnikov in zaplat morskih trav $v$ Semedelskem zalivu. V preteklosti je preučevanje morskih travnikov zahtevalo uporabo zamudnih metod in dalo le okvirne podatke, uporaba sodobnih načinov zajemanja podatkov in GIS-orodij pa omogoča obsežnejše raziskave in natančnejše podatke. S sonarskim snemanjem in fotografiranjem iz zraka smo pridobili podatke, ki smo jih s pomočjo geografskih informacijskih sistemov analizirali in ugotovili, da se površina dna $v$ Semedelskem zalivu pokritega $z$ morskimi travniki povečuje, kar kaže na izboljšanje kakovostnega stanja obalnega morja, zlasti na manjšo motnost vode in manjši dotok hranil s kopnega. Obseg večjih morskih travnikov se je v obdobju 2009-2015 povečal za 8,6 ha ter danes pokrivajo že 45,6\% dna. Morski travniki so se v največji meri povečali s pomikom spodnje meje $v$ globlje dele zaliva in $z$ razraščanjem posameznih zaplat $v$ izlivnem območju Badaševice.

\section{KLJUČNE BESEDE}

morske trave, morski travnik, ekološko stanje, GIS, Badaševica, Semedelski zaliv

\section{ABSTRACT}

The changes of seagrass meadows on the Semedela Bay seabed in the period 2009-2015

The paper presents the results of a several-year long research of the range and changes in the extent of marine meadows and patches of seagrass in the Semedela Bay (Slovenia). In the past, such investigation required the use of time-consuming methods and resulted only in raw data, whereas the use of modern methods of collecting data and the GIS tools enable more extensive research and give more accurate data. Sonar mapping and air photography provided information which we analysed by means of Geographic Information Systems. We have established that the extent of the marine meadows in the Semedela Bay has been increasing, which indicates that the quality of the coastal seawater has improved; particularly its cloudiness has decreased and so has the inflow of nutrient matter from the land. The extent of larger marine meadows increased in the 2009-2015 period by 8.6 ha, so that nowadays they cover as much as $45.6 \%$ of the seabed. They mostly have been enlarged by moving the lower 
border into deeper parts of the Semedela Bay and by growing individual patches in the mouth area of the river Badaševica.

\section{KEY WORDS}

seagrasses, marine meadow, ecological state, GIS, Badaševica, Semedela Bay

Uredništvo je prispevek prejelo 7. februarja 2018. 


\section{Uvod}

Veliko obalnih ekosistemov na Zemlji v zadnjih desetletjih doživlja krčenje razširjenosti morskih travnikov ali celo njihovo izginotje. Vzroki, ki niso natančno preučeni, so tako naravnega kot antropogenega izvora. Človek večinoma prispeva $h$ krčenju površin morskih travnikov s povečanim obremenjevanjem okolja $\mathrm{v}$ povodjih ali $\mathrm{z}$ neposrednim obremenjevanjem morja. Rast gospodarskih dejavnosti vodi do povečanih vnosov hranil in povečane motnosti vode (Lathrop s sodelavci 2001). Krčenje in izginjanje morskih travnikov je še toliko bolj zaskrbljujoče zaradi pomembne ekološke vloge, ki jo imajo v obalnih ekosistemih. Glede na dobrine in ekosistemske storitve, ki jih omogočajo, so morski travniki namreč eden najpomembnejših morskih ekosistemov (Telesca s sodelavci 2015). Poleg tega so morske trave tudi dober pokazatelj ekološkega stanja, saj odražajo součinkovanje vplivov človeka na okolje ter posledice njegovih negativnih vplivov v preteklosti. So odličen indikator, na katerega se lahko oprejo okoljski monitoringi in strategije upravljanja obalnega morja po vsem svetu (Peterlin 2013). Stanje ter razširjenost morskih travnikov torej odražata kakovost obalnega vodnega okolja in spremembe njihove porazdelitve opozarjajo na spremembe kakovosti vode. S tem nam tudi omogočijo učinkovito ukrepanje za doseganje zmanjšanja onesnaženosti obalnih ekosistemov in zagotavljanje trajnostne rasti (Dennison s sodelavci 1993; Krause-Jensen s sodelavci 2004).

Zaradi ekološke vrednosti morskih travnikov je bilo na njihovih območjih opravljenih že mnogo raziskav, kljub temu pa so procesi in spremembe slabo poznani ter je težko oceniti obseg njihovih ekosistemskih storitev. Poglavitni razlog je v pomanjkljivih podatkih o njihovi površini in stanju (na primer gostoti zarasti). Kartiranje morskih travnikov, kot večina prostorskih študij, je bilo namreč v preteklosti omejeno tako $\mathrm{z}$ upravljanjem toka zbiranja podatkov kot tudi $\mathrm{z}$ načini njihovega shranjevanja in obdelave. Prostorski vzorci so bili običajno interpolirani iz nekaj prostorsko ozko omejenih točk. Kartiranje morskih travnikov so večinoma izvajali le s potapljaškimi opazovalnimi metodami, ko so na določenih linijskih presekih popisali vse habitatne tipe, nato pa so pridobljene prostorske podatke interpolirali oziroma posplošili na celotno območje. Čeprav so podrobne raziskave manjših območij (vzorčnih mest) morskega dna s pomočjo vzorčenja in potapljanja vsekakor nujne za pridobivanje novega znanja ter spremljanje stanja morskih ekosistemov, so večinoma prostorsko in časovno pomanjkljive (Finkl in Makowski 2014). Omejitve preučevanja pa so se v veliki meri zmanjšale z razvojem geografskih informacijskih sistemov (GIS-ov) in tudi z razvojem tehnik daljinskega zaznavanja (Robbins 1996). GIS-i so postali najpomembnejše orodje kvantitativne geografije, saj ponujajo možnosti za pridobivanje in analiziranje prostorsko razporejenih podatkov ter lahko odgovorijo na vprašanja, povezana $\mathrm{z}$ neenakomerno porazdelitvijo organizmov in njihovih virov, $\mathrm{v}$ povezavi s procesi, ki vplivajo na razporeditev tako časovno kot prostorsko (Johnston 1990). Primer praktične uporabe GIS-ov je tudi odkrivanje časovnih sprememb habitatov, uporabljeno tudi pri morskih travnikih (Remillard in Welch 1992). So namreč zelo uporabni za količinsko oceno habitatov morskih trav v plitvih estuarijih in obalnih območjih ter za preučevanje časovnih sprememb površine morskih travnikov. Postali so pomembno orodje za kartiranje, obdelavo in interpretacijo okoljskih podatkov o obalnih območjih, povodjih in izlivnih območjih rek. V navedenih okoljih je namreč veliko biokemijskih lastnosti vodnih teles medsebojno povezanih in v mnogih primerih kažejo prostorsko odvisnost (Robbins 1996).

Namen raziskave je bilo odkrivanje časovnih sprememb pokritosti dna z morskimi travami v Semedelskem zalivu. Območje je v preteklosti veljalo za okoljsko zelo obremenjeno zaradi neposrednih izpustov neprečiščenih odpadnih voda v morje ter onesnažil in sedimentov, ki jih je v zaliv prinašala Badaševica. Pogoji za rast morskih trav so bili zaradi navedenega omejeni in spreminjanje pokritosti dna z morskimi travami je odražalo ekološke pogoje v zalivu. Zanimalo nas je, kakšne so spremembe med letoma 2009 in 2015, potem ko se je odvajanje odpadnih voda v Mestni občini Koper izboljšalo zaradi priključitve na komunalno čistilno napravo, in ali se kaže vpliv izliva Badaševice, ki po obilnejših padavinah priteka zelo motna, njene vode pa so zaradi tokovanja odrinjene proti severni obali zaliva. 


\section{Metode}

\subsection{Območje preučevanja}

Raziskava je obsegala območje Semedelskega zaliva kot skrajnega jugovzhodnega dela Koprskega zaliva, ki leži med Žusterno in starim mestnim jedrom Kopra. Je plitev zaliv, s povprečno globino $6 \mathrm{~m}$ (Digitalni ... 2008) in površino $0,43 \mathrm{~km}^{2}$, če ga omejimo z izobato $6 \mathrm{~m}$, od Žusterne do koprskega ribiškega pomola (slika 1). Njegova obala ima, kljub antropogenim spremembam, značilnosti akumulacijskega tipa obale, ki ga je oblikovala reka Badaševica in dno zaliva debelo prekrila s sedimenti (mulj). Badaševica zaradi svojega erozijsko slabo odpornega flišnega zaledja prinaša obilico drobnega gradiva, ki se odlaga v morju (Malačič 1994; Orožen Adamič 2002). Njen vpliv se kaže tudi v fizikalno-kemijskih lastnostih morske vode $\mathrm{v}$ zalivu, ki so povezane $\mathrm{z}$ dinamiko pretoka in lastnosti vode Badaševice. Na gibanje in lastnosti vodnih mas $\mathrm{v}$ zalivu pa vplivajo tako vremenske kot tudi oceanografske razmere (Steinman s sodelavci 2004). Semedelski zaliv zato predstavlja svojevrstno življenjsko okolje, ki se po naravnih značilnostih loči od osrednjega dela Koprskega zaliva in ga je smiselno obravnavati ločeno. Mešanje morske in sladke vode se med letom močno spreminja, s tem se spreminjajo ekološki pogoji in območje je zato primerno tudi za preučevanje vpliva spremenljivih lastnosti vode na poraslost dna zaliva $\mathrm{z}$ morskimi travami. V Semedelskem zalivu je razširjena združba s kolenčasto cimodocejo (Cymodocea nodosa), ki porašča zgornji del infralitorala, v globinskem razponu od 2 do $10 \mathrm{~m}$, za katerega so značilne šibke hidrodinamične razmere. V zalivu je prisotna tudi združba s pravo morsko travo (Zostera marina), ki se pojavlja v obliki morskega travnika. Travnik je lepo razvit, v osrednjem delu pa je tudi zelo gost (Lipej, Turk in Makovec 2006).

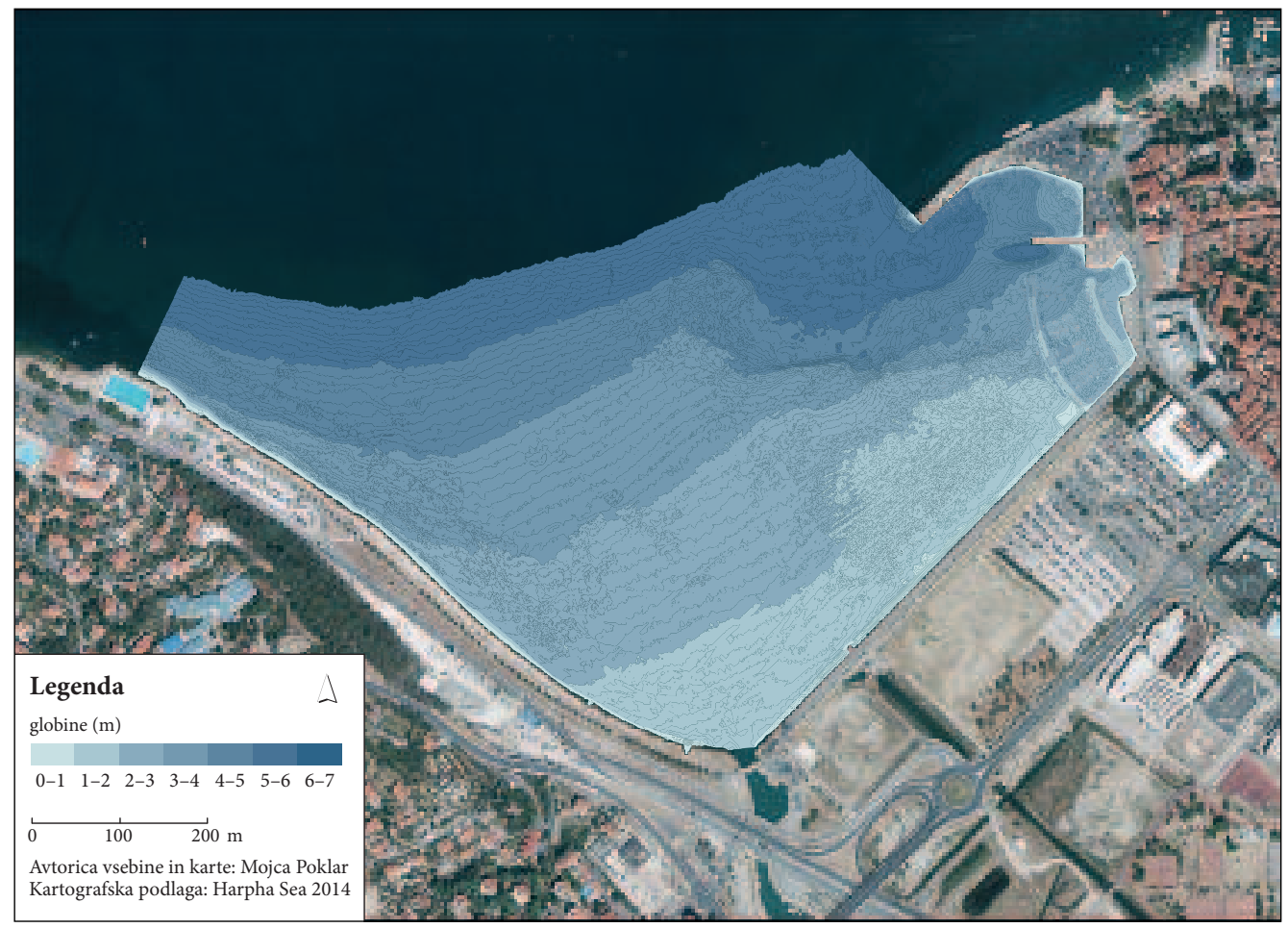

Slika 1: Globine območja preučevanja v Semedelskem zalivu. Ločljivost globin je 0,5 $\mathrm{m} \times 0,5 \mathrm{~m}$. 


\subsection{Operativna opredelitev morskega travnika in kartiranje}

Za določanje površine morskega travnika je pomembno, da ga pravilno omejimo. Tu se pogosto pojavljajo težave, saj meja morskega travnika ni enostavno določljiva (Virnstein, Avery in Johansson 2000). V tej raziskavi je bila zato uporabljena operativna opredelitev morskih travnikov (Virnstein, Avery in Johansson 2000) in najmanjša enota kartiranja morskih travnikov velikosti 0,01 ha. Da bi z opredelitvijo morskega travnika zajeli tako gosto porasla območja z morsko travo kot nesklenjena območja $\mathrm{z}$ morsko travo, smo po metodi operativne opredelitve opravili klasifikacijo morskega dna v tri tipe:

- sklenjen morski travnik (površina morskega travnika je večja ali enaka 0,01 ha),

- območje nesklenjenega pojavljanja morske trave (več manjših zaplat morske trave, manjših od 0,01 ha),

- območje neporaslega dna oziroma mulj.

Opredelitvi morskih travnikov sta sledila kartiranje in izdelava kartografskih prikazov, ki je slonela na podatkih razširjenosti morskih trav, pridobljenih z dvema metodama daljinskega zaznavanja, to sta sonarsko snemanje in zračno fotografiranje. $Z$ večsnopnim sonarjem so bile izvedene podrobne batimetrične meritve Semedelskega zaliva, iz katerih smo nato sestavili digitalni batimetrični model (Moškon, Žibert in Kavšek 2015). Ta je služil kot podlaga za kartiranje morskih travnikov. S pomočjo fotografiranja iz zraka smo dobili fotografije, ki so bile s programsko opremo AutoPanoGiga združene v skupno fotografijo celotnega območja preučevanja. Skupna zračna fotografija je bila nato georeferencirana v programskem okolju ArcGIS, iz slednje pa smo nato digitalizirali morske travnike. Digitalizacija je potekala $\mathrm{z}$ nadzorovano klasifikacijo zračne fotografije, $\mathrm{v}$ kombinaciji z njeno vizualno interpretacijo. Uporabili smo metodo največje verjetnosti, saj je najbolj natančna, kljub temu, da je računalniško zahtevna (Oštir 2006). Kakovost klasifikacije je bila izboljšana z vizualno interpretacijo celotne fotografije, kjer smo z ovrednotenjem osnovnih elementov vizualne interpretacije fotografij (na primer ton, oblika, velikost, vzorec, tekstura, sence) ročno popravili meje morskih travnikov, kar je najbolj subjektivni del metode.

Obe metodi daljinskega zaznavanja sta bili preverjeni z metodo linijskih presekov in središčnih točk morskih travnikov, kjer je bilo s pomočjo podvodnih fotografij, pridobljenih iz videoposnetka, mogoče preveriti stanje morskih travnikov na posameznem linijskem preseku oziroma središčni točki. Ker je metoda sonarskega snemanja bolj zanesljiva (93,3 \% zanesljivost) od metode zračnega fotografiranja $(63,3 \%)$ (Poklar 2015), so bili za izdelavo podatkovnih slojev morskih travnikov v 70-75\% primerov upoštevani izmerjeni sonarski podatki, na območjih, kjer so travniki redkejši in jih je s sonarjem težko ločiti od mulja, pa smo jih dopolnili s podatki zračne fotografije.

Iz podatkov, pridobljenih s sonarskim snemanjem, zračnimi fotografijami in podvodnim snemanjem, smo izdelali prikaze tipov morskega dna v Semedelskem zalivu. Morsko dno smo razčlenili v zgoraj omenjene tri tipe: morski travnik, območje nesklenjenega pojavljanja zaplat morske trave in neporaslo dno oziroma mulj. V primerjalni analizi, opisani v nadaljevanju, smo upoštevali le prvega, to so morski travniki.

\subsection{Primerjalna analiza poraslosti dna $\mathrm{z}$ morskimi travniki}

Zaradi svetovnega trenda zmanjševanja površin morskih travnikov (Duarte 2002) smo želeli ugotoviti, kaj se dogaja v Semedelskem zalivu in izvedli prostorsko-časovno analizo spreminjanja pokritosti morskega dna z morskimi travniki. Primerjalna analiza obsega šestletno obdobje 2009-2015, a smo zanjo uporabili zgolj fotografije, posnete $v$ pomladansko-poletnem času. Rast morske trave se kaže v letni dinamiki, ki je v veliki meri odvisna od letnih časov in spremljajočih sprememb okoljskih pokazateljev, kot sta na primer temperatura in osvetljenost. Čeprav je pri vseh vrstah trav v Semedelskem zalivu podzemni del med letom precej stalen, pa se število in velikost listov pri nekaterih vrstah med letom bolj spreminjata kot pri drugih. Te spremembe so očitne predvsem pri cimodoceji (Cymodocea nodosa), ki predstavlja večino v pokritosti dna $\mathrm{z}$ morskimi travami tudi v Semedelskem zalivu. Povprečno 
število poganjkov, povprečno število listov na poganjku ter povprečna velikost listov (dolžina in širina) so pozimi precej manjši kot poleti (Cancemi, Buia in Mazzella 2002). Iz slike 2 je razvidno, da je v poletnem času kolenčasta cimodoceja $\mathrm{v}$ "polnem razcvetu«, medtem ko je pozimi težko opazna kljub njeni prisotnosti. Za primerjalno analizo smo zato upoštevali le snemanja, ki smo jih opravili v pomladansko-poletnem času in dobili bolj zanesljive podatke o razširjenosti morskih trav. Zračne fotografije morskih travnikov so bile posnete: 22. 6. 2009, 22. 6. 2010, 19. 5. 2011, 18. 5. 2012, 24. 5. 2013, 21. 5. 2014 in 29.5.2015.

Z GIS-orodjem (ESRI ArcGIS) smo nato za vsako leto posebej izdelali podatkovni sloj poligonskega tipa in za vsak sloj izračunali površino (v ha). Iz podatkovnih slojev smo z metodo prekrivanja izdelali

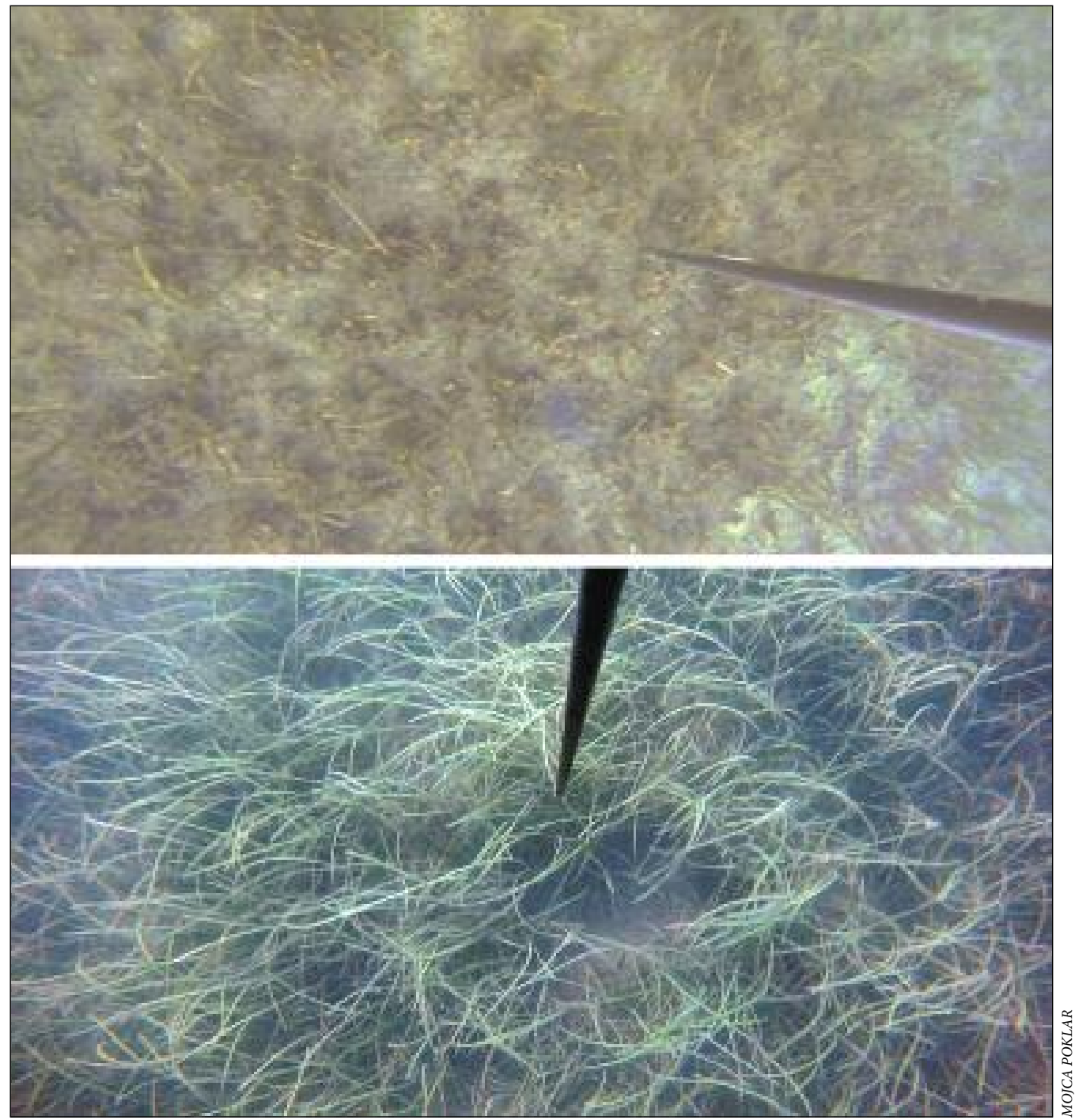

Slika 2: Razlika v razrasti trav (številu poganjkov, številu listov na poganjku ter velikosti listov) pozimi (zgoraj; 19.2.2015) in poleti (spodaj; 6. 7.2014). 
zemljevide skladnosti, in sicer za obdobja 2009-2011, 2011-2013 in 2013-2015. Razlike v razširjenosti morskih travnikov v izbranih obdobjih smo ugotavljali s pomočjo naslednjega postopka (Barsanti s sodelavci 2007):

1) delež morskega travnika, prisotnega le v letu $X$ :

$$
\frac{A}{(A+B+C)} \times 100
$$

2) delež morskega travnika, prisotnega le v letu $Y$ :

$$
\frac{B}{(A+B+C)} \times 100 \text {; }
$$

3) delež morskega travnika, prisotnega v obeh letih:

$$
\frac{C}{(A+B+C)} \times 100 \text {. }
$$

$X$ in $Y$ sta obravnavani leti, $A$ je površina travnika (v ha), ugotovljena v letu $X$ in ne v letu $Y, B$ je površina travnika (v ha), ugotovljena v letu $Y$ in ne v letu $X$; $C$ pa je skupna površina travnika (v ha), ugotovljena v letih $X$ in $Y$. Na podlagi izračunov smo naredili primerjavo razširjenosti morskih travnikov in interpretirali razlike $\mathrm{v}$ površini, ki smo jih ugotovili v preučevanem obdobju.

\section{Rezultati in razprava}

\subsection{Pokritost dna z morskimi travami v Semedelskem zalivu leta 2015}

Velik del morskega dna predstavlja neporaslo dno oziroma mulj, ki mu pripada 16,90 ha ali 39,1\% dna Semedelskega zaliva. Njegov izvor so rečne naplavine Badaševice ter erodirane flišne kamnine z obale. Neporaslo dno oziroma mulj je viden neposredno ob obali, predvsem od izlivnega območja Badaševice proti Žusterni, v koprskem mandraču ter na dnu, globljem od 5,5 m, kjer svetlobne razmere ne omogočajo rasti morske trave. Plitvejše muljasto dno pokrivajo manjše zaplate morske trave, ki smo jih uvrstili v tip nesklenjenega pojavljanja morske trave. Ta je leta 2015 pokrival 6,66 ha ali 15,4\% dna Semedelskega zaliva. Ponekod zaplate morske trave že oblikujejo manjše morske travnike, ki pa še ne presegajo velikosti 0,01 ha.

V Semedelskem zalivu sta dva večja morska travnika ter veliko manjših. Večji morski travnik (MT 1) je na sliki 3 viden na vzhodni strani, kjer se od Semedelske ceste širi proti severozahodu. Leta 2015 je segal od globine $0,3 \mathrm{~m}$ pri obali do globine $5,26 \mathrm{~m}$; meril je 12,2 ha in je bil širši ob obali, kjer je v najširšem delu meril $500 \mathrm{~m}$, njegova največja dolžina pa je bila $470 \mathrm{~m}$. Morski travnik oblikujeta prava morska trava (Zostera marina) in kolenčasta cimodoceja (Cymodocea nodosa). Drugi večji morski travnik (MT 2) oblikuje kolenčasta cimodoceja (Cymodocea nodosa) in se razprostira v zahodnem delu, kjer se širi vzdolž Istrske ceste od Žusterne proti izlivu Badaševice. Morski travnik je več kot pol manjši od mešanega morskega travnika v vzhodnem delu zaliva, saj je bila njegova površina ocenjena na 5,98 ha. Največja izmerjena širina v smeri od obale je bila okoli $180 \mathrm{~m}$ in najmanjša $35 \mathrm{~m}$. Najgloblje, do $5 \mathrm{~m}$, sega v skrajnem severozahodnem delu. Na sliki 3 je vidnih tudi več manjših morskih travnikov, katerih površine so od 0,01 do 0,25 ha in jih oblikuje prav tako kolenčasta cimodoceja.

\subsection{Analiza sprememb pokritosti dna z morskimi travniki v obdobju 2009-2015}

Površina dna Semedelskega zaliva, pokritega z morskimi travniki, se je v obdobju 2009-2015 povečevala. Leta 2009 so morski travniki poraščali skupaj 11,08 ha, leta 2010 je njihova površina narasla za skoraj 1 ha in presegla 12 ha. Zelo malo se je povečala leta 2011, ko smo izmerili 12,19 ha skupne površine. Leta 2012 se je površina dna, pokritega z morskimi travniki, povečala na 13,37 ha in leta 2013 


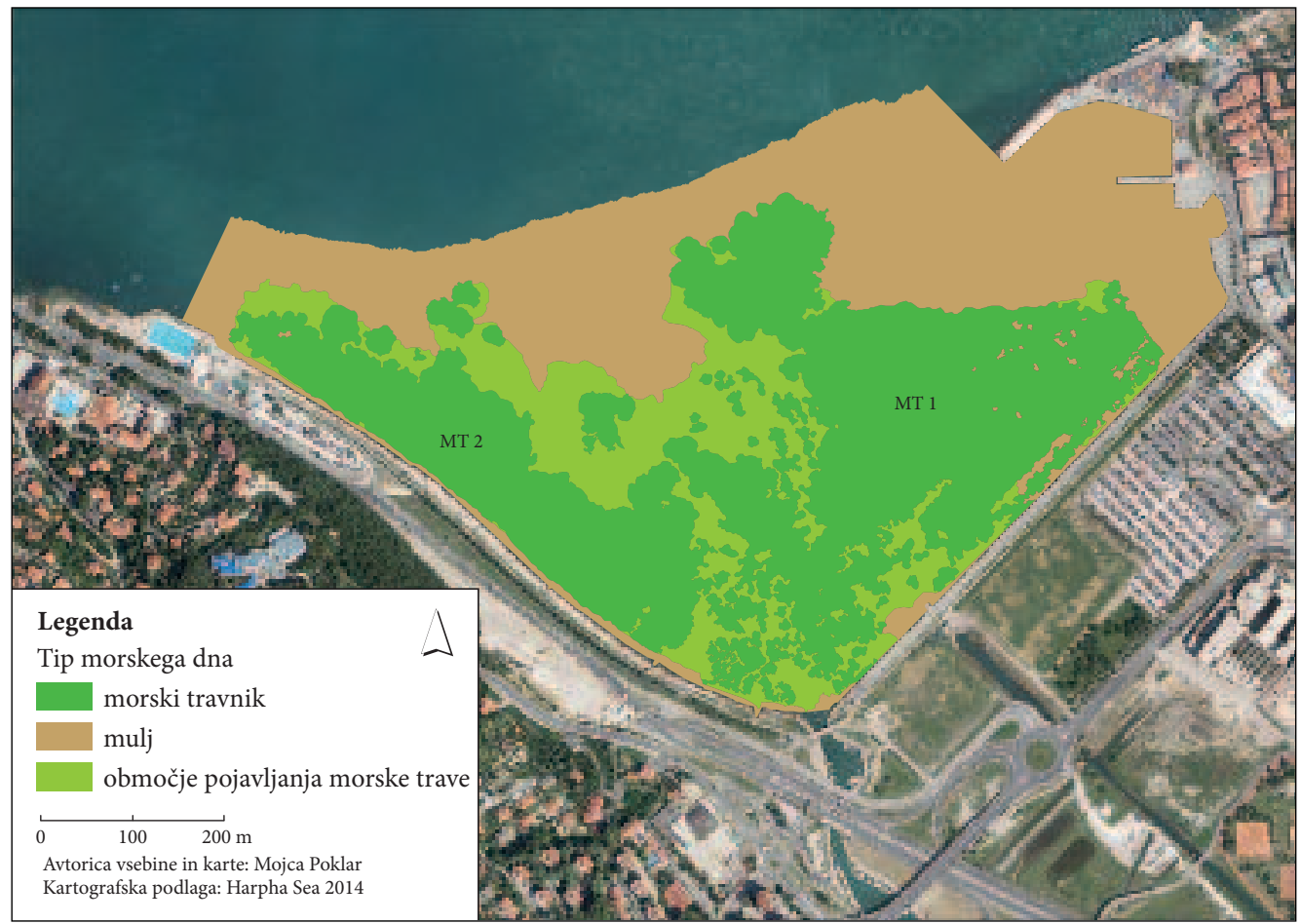

Slika 3: Razširjenost tipov morskega dna v Semedelskem zalivu maja 2015.

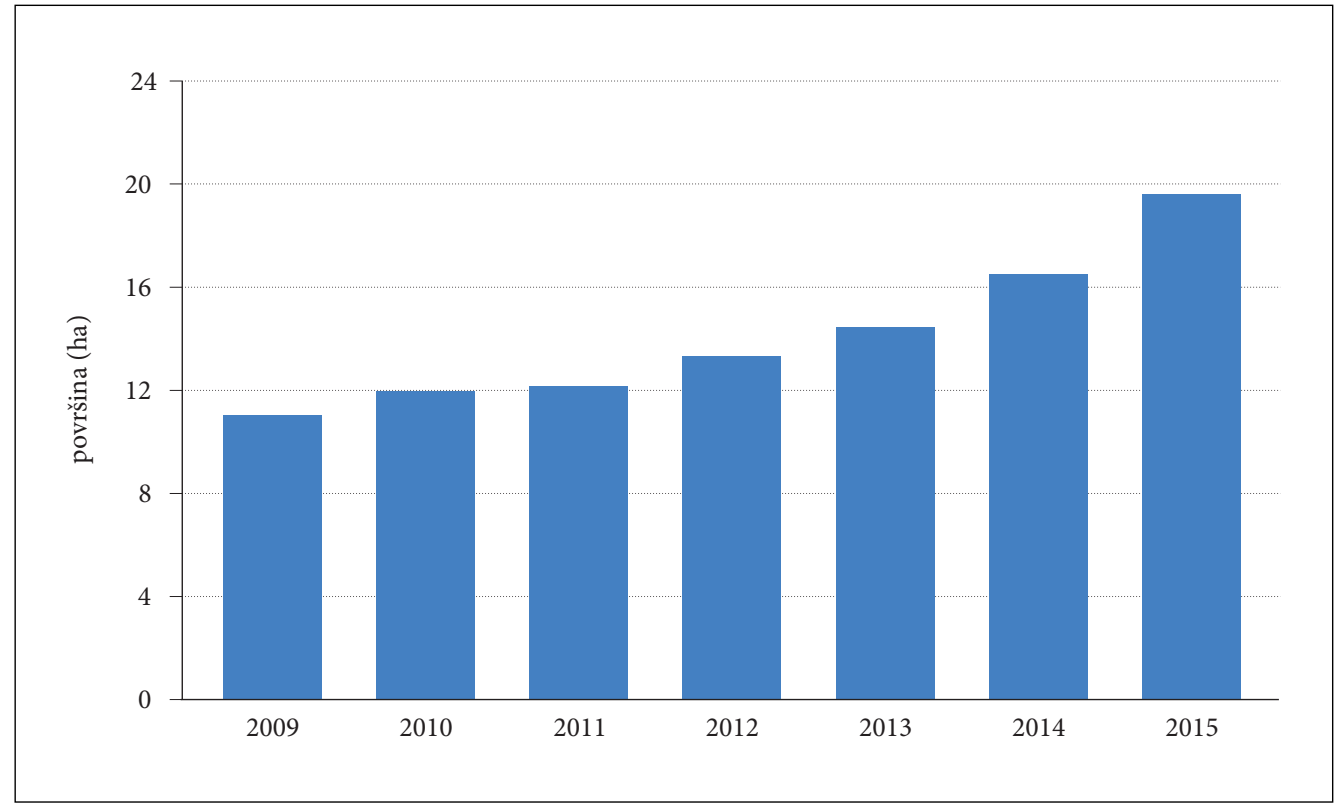

Slika 4: Površina morskih travnikov v Semedelskem zalivu v obdobju 2009-2015. 
na 14,47 ha. V zadnjih dveh letih obravnavanega obdobja so se morski travniki najbolj povečali. Leta 2014 je bila skupna površina že 16,54 ha, leta 2015 pa kar 19,65 ha. Površina morskih travnikov se je tako od začetka do konca obravnavanega obdobja povečala za 8,57 ha ali za $44 \%$.

Da smo lahko pojasnili spreminjanje prostorske razporeditve pokritosti dna z morskimi travniki, smo za obdobja 2009-2011, 2011-2013 in 2013-2015 izvedli analizo skladnosti, rezultate katere prikazujejo slike 5, 6 in 7. Na sliki 5 je vidna le malo povečana površina morskega travnika kolenčaste cimodoceje (MT 2) v obdobju 2009-2011. Povečala se je predvsem sklenjenost poraščenosti v notranjosti morskega travnika, medtem ko je na globinsko spodnji meji travnika opaziti izginjanje nekaterih manjših zaplat. Manjši mešani morski travnik (MT 1) se je razširil zlasti v jugozahodni smeri, medtem ko se je njegova zgornja meja pri obali poglobila z 1,1 na 1,3 $\mathrm{m}$. To bi lahko bila posledica prenove semedelske promenade leta 2010, ko so poglobili tudi pas morskega dna vzdolž nje. Globinska spodnja meja morskega travnika se je v severnem oziroma severozahodnem delu premaknila v plitvejše vode. Razlika v globini je na nekaterih delih dosegla tudi $1 \mathrm{~m}$. Delež skupne površine morskih travnikov, prisotnih v letih 2009 in 2011, je zajemal $73 \%$, povečan del leta $201118 \%$, medtem ko je krčenje predstavljalo $9 \%$.

Morska travnika sta se v obdobju 2011-2013 razširila za 2,3 ha. Na sliki 6 je vidna razširitev tako morskega travnika MT 2 kot morskega travnika MT 1. Prvi se je razširil v smeri globljega dna in globinska spodnja meja je dosegla celo 5,4 m. Mešani morski travnik MT 1 pa se je razširil v smeri proti izlivu Badaševice ter $\mathrm{v}$ smeri od obale, $\mathrm{s}$ čimer se je tudi tu poglobila njegova spodnja meja pod $5 \mathrm{~m}$ globine. $\mathrm{Na}$ širjenje travnikov na globlje dno bi lahko vplivala manjša motnost vode, kar omogoča lažje prodiranje svetlobe do morskega dna tudi v večjih globinah. Zgornji globinski meji obeh travnikov sta večinoma ostali enaki, le morski travnik MT 2 se je v srednjem delu poglobil. Meja se je premaknila z najmanjše globine 1,45 m na globino 2,9 m. Skupna površina morskih travnikov, prisotna v obeh letih, je bila $78 \%$, povečan del $19 \%$, krčenje pa je bilo zanemarljivo (3\%).

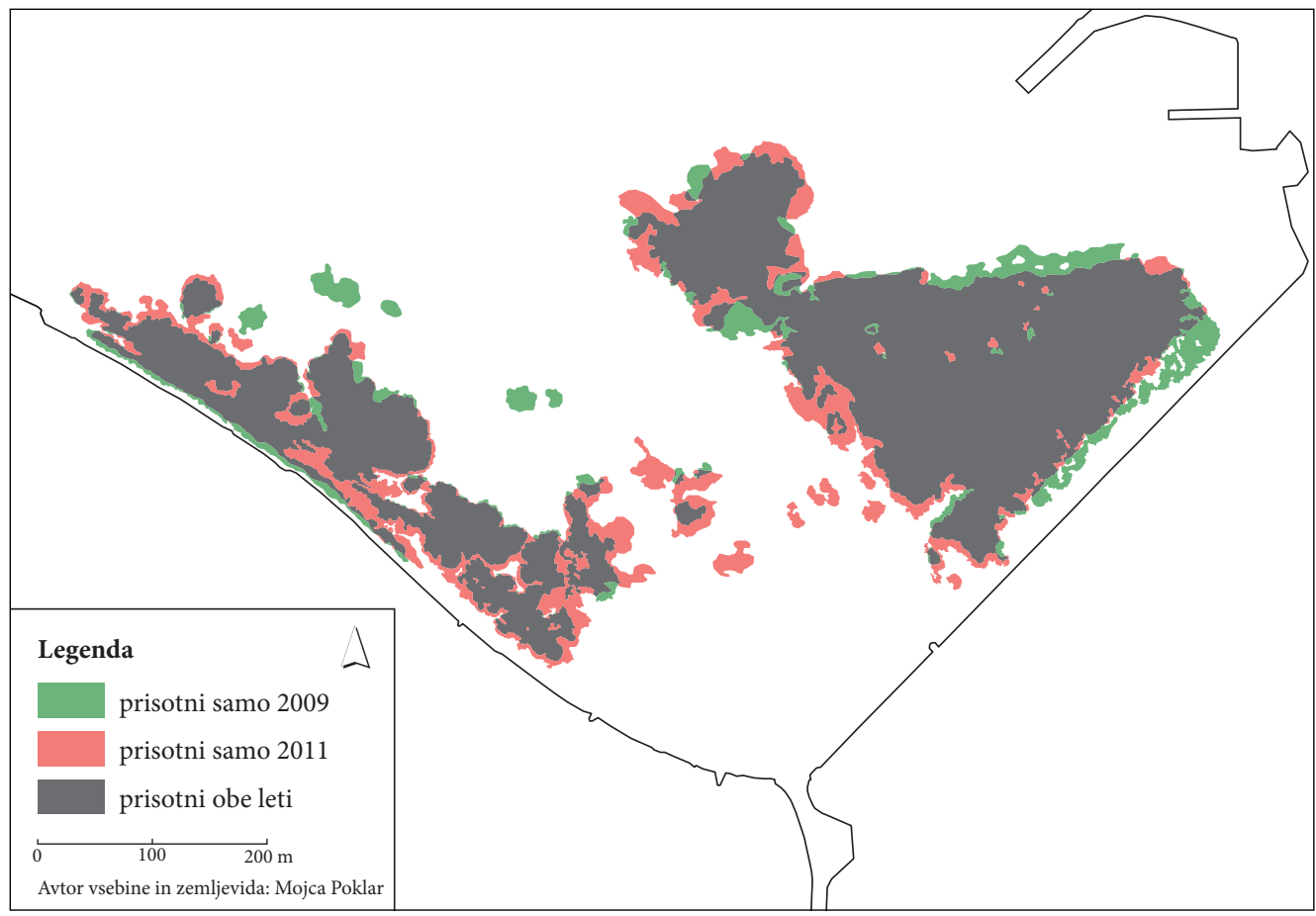

Slika 5: Prikaz skladnosti morskih travnikov v obdobju 2009-2011. 


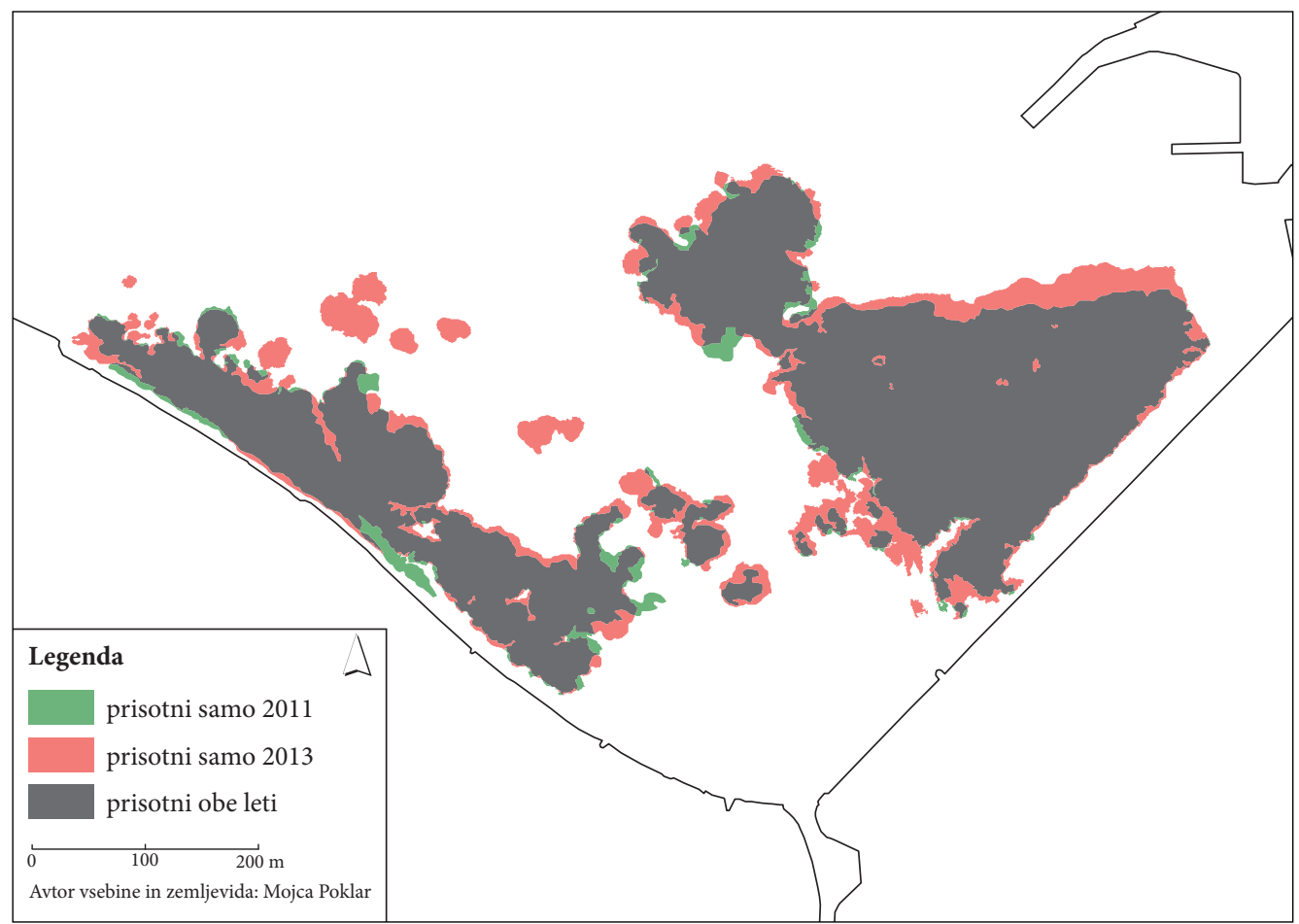

Slika 6: Prikaz skladnosti morskih travnikov v obdobju 2011-2013.

V zadnjem opazovanem obdobju 2013-2015 je opazna največja sprememba v razširjenosti morskih travnikov, saj se je njihova površina povečala za kar 5,2 ha. Na sliki 7 je vidna razširitev obeh večjih, prav tako pa so se razrasli tudi manjši morski travniki, predvsem v izlivnem območju Badaševice. Pri morskem travniku MT 2 je v njegovem severozahodnem delu vidna bolj sklenjena poraščenost v notranjosti morskega travnika, večja sprememba pa je opazna v njegovem jugovzhodnem delu, kjer se je razširil proti obali in se je spremenila zgornja globinska meja, ter v vzhodnem delu, kjer se razrašča proti izlivu Badaševice. Povečanje je prav tako opazno pri mešanem morskem travniku MT 1, kjer se je njegov jugozahodni del združil z manjšimi morskimi travniki, prisotnimi že leta 2013. Na območju ob izlivu Badaševice pa je opaznih več manjših morskih travnikov, kar kaže na to, da Badaševica nima več negativnega vpliva na rast morske trave in na ekološko stanje Semedelskega zaliva. To je pokazala že prostorska analiza sprememb pokazateljev lastnosti vode (Poklar 2015). Pri mešanem morskem travniku MT 1 je opaziti manjšo razrast v najglobljem delu morskega travnika ter večjo v njegovem najplitvejšem območju. Zgornja meja morskega travnika se je premaknila iz globine nad $1 \mathrm{~m}$ celo do globine $0,2 \mathrm{~m}$. Krčenje, sicer majhno (4\%), je opazno pri spodnji meji morskega travnika ob koprskem mandraču, kjer se je ta pomaknila v smeri proti obali. Skupna površina morskih travnikov, prisotna v obeh letih, je predstavljala $67 \%$, povečan del pa $29 \%$.

\section{Sklep}

S pomočjo sonarskega snemanja in fotografiranja iz zraka smo dobili dovolj kakovostne podatke, ki smo jih še dodatno preverili s podvodno fotografijo ter izvedli kartiranje razširjenosti rastišč mor- 


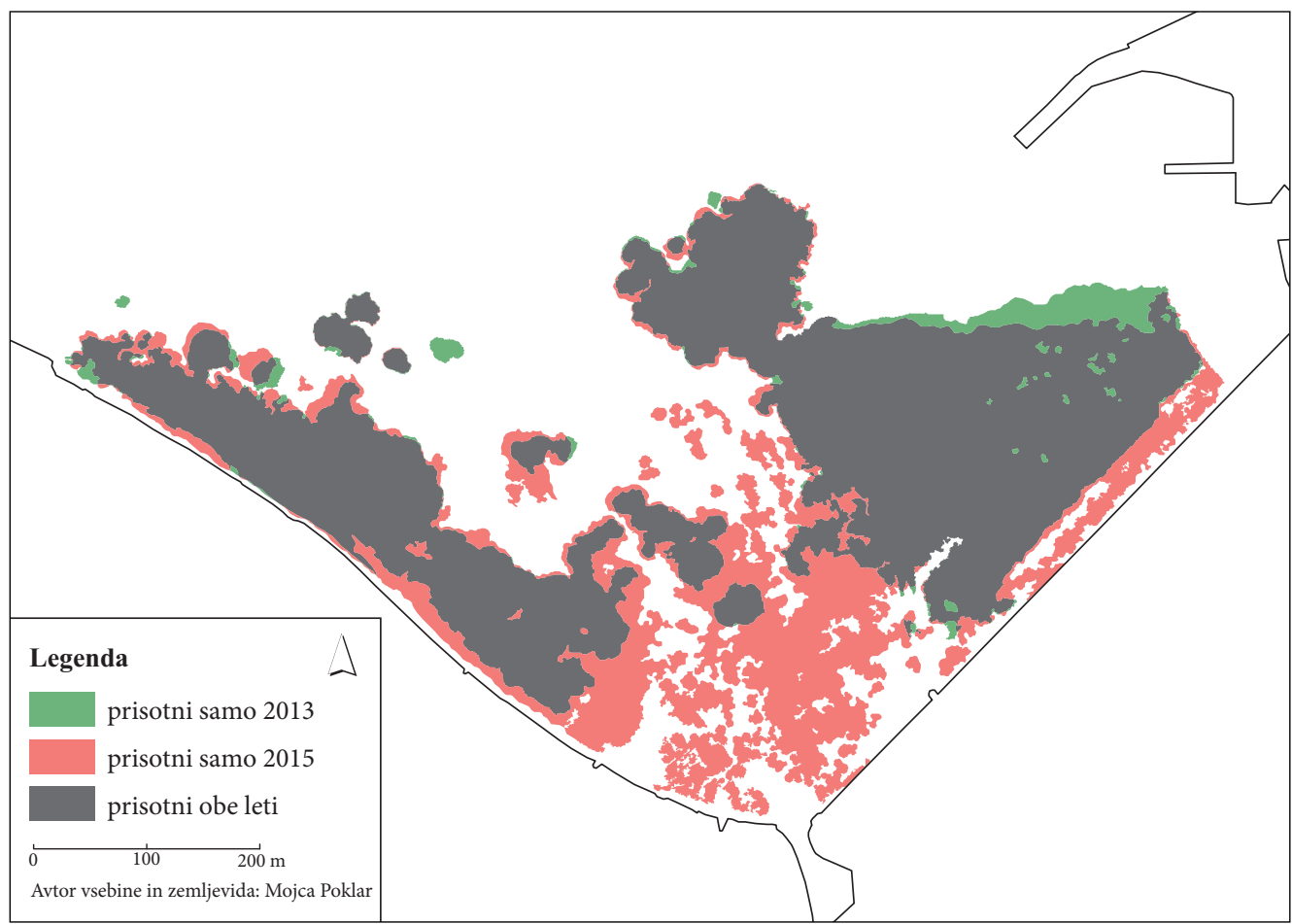

Slika 7: Prikaz skladnosti morskih travnikov v obdobju 2013-2015.

skih trav v Semedelskem zalivu. Prvi prikaz tipov pokritosti morskega dna z morskimi travami je bil izdelan za leto 2009, postopek zajema in obdelave podatkov pa smo ponovili še v letih 2011, 2013 in 2015. V prispevku je prikazano stanje leta 2015 , ko je bilo $39,1 \%$ dna neporaslega, $15,4 \%$ pokritega $\mathrm{z}$ nesklenjenimi zaplatami morskih trav, manjšimi od 0,1 ha, ostalo pa so pokrivali morski travniki. Z analizo stanj v posameznih letih smo dobili vpogled v časovno-prostorske spremembe pokritosti dna z morskimi travniki v obdobju 2009-2015. Skupna površina morskih travnikov se je v preučenem obdobju povečala za 8,57 ha ali za $44 \%$, kar je zelo pozitivno v smislu preprečevanja svetovnega trenda krčenja morskih travnikov. Leta 2009 je bil delež dna Semedelskega zaliva, pokritega z morskimi travniki, 25,7\%; do leta 2013 se je delež povečal na 33,5\% in do leta 2015 na 45,5\%.

V Semedelskem zalivu se razprostirata dva večja sklenjena morska travnika. Manjšega (5,98 ha) gradi predvsem kolenčasta cimodoceja (Cymodocea nodosa), večjega (12,2 ha) pa poleg kolenčaste cimodoceje še prava morska trava (Zostera marina).

$S$ pomočjo analize skladnosti smo ugotovili, za koliko in kam sta se razširila travnika oziroma kam so se pomaknile zunanje meje. Ugotovili smo, da so se spodnje globinske meje obeh travnikov znižale in leta 2015 segajo opazno globlje kakor leta 2009. Ker sta obe prevladujoči vrsti morske trave (Cymodocea nodosa in Zostera marina) občutljivi predvsem na povečano motnost morske vode, ki je v veliki meri kriva za njihovo krčenje v svetovnem merilu, bi lahko širjenje morskih travnikov na globlje dno kazalo na manjšo motnost vode v Semedelskem zalivu. Razloge za slednjo bi lahko iskali v stabilizaciji sedimenta in manjši vzvalovanosti kot glavnem vzroku dviganja sedimenta ter v manjšem transportu sedimentov z vodami Badaševice. Spodnja globinska meja se je zvišala le pri mešanem morskem travniku pri koprskem mandraču, kar bi lahko pripisali posegom v morsko dno, in sicer umetnemu poglabljanju in sidranju manjših plovil na tem območju. 
Posebej zanimivo pa je širjenje morskih travnikov vzdolž obale in proti izlivu Badaševice. V preteklosti je reka Badaševica $\mathrm{v}$ zaliv prinašala onesnažene in predvsem $\mathrm{s}$ hranili bogate vode, kar naj bi prispevalo k izredno osiromašenemu rastju na njenem izlivnem območju. Tako kolenčasta cimodoceja kot prava morska trava sta namreč občutljivi na povišane vsebnosti hranil v vodnem stolpcu (Lipej, Turk in Makovec 2006; Orfanidis, Papathanasiou in Gounaris 2007). Širjenje morskih travnikov proti izlivu Badaševice, ki je izrazito predvsem v zadnjem opazovanem obdobju (2013-2015), pa kaže ravno nasprotno. Že prostorska analiza sprememb pokazateljev lastnosti vode, med drugimi tudi motnosti, je v hidrološkem letu 2012-1013 pokazala, da so vplivi dotoka Badaševice na fizikalno-kemijske lastnosti morja v zalivu zelo omejeni (Poklar 2015). Prostorske vplive Badaševice in Rižane na temperaturo in slanost v Koprskem zalivu so obravnavali Soczka Mandac in sodelavci (2014) ter ugotovili, da lahko v določenih pogojih predvsem reka Rižana vpliva na Semedelski zaliv. Soczka Mandac in Faganeli (2015) sta ocenila posedanje suspendiranih delcev, ki jih reke vnašajo v Koprski zaliv in povprečno koncentracijo celotne suspendirane snovi (TSS) v površinskem sloju $(0,5 \mathrm{~m}) \mathrm{na} 4 \mathrm{mg} / \mathrm{l}$. Avtorja sta povečano koncentracijo TSS $v$ Semedelskem zalivu povezala $\mathrm{z}$ vplivom vetra in valovanja, $\mathrm{v}$ manjši meri pa $\mathrm{z}$ vplivom rek. Z Badaševico pritekajo v Semedelski zaliv namreč razmeroma skromne količine sladke vode. Srednji letni pretok je bil v obdobju $1994-20130,24 \mathrm{~m}^{3} / \mathrm{s}$; povprečni najmanjši julija $\left(0,07 \mathrm{~m}^{3} / \mathrm{s}\right)$ in povprečni največji decembra $\left(0,39 \mathrm{~m}^{3} / \mathrm{s}\right)$. Izjemno stanje s pretokom $0 \mathrm{~m}^{3} / \mathrm{s}$ je bilo na Badaševici zabeleženo večkrat, največji pretok 10,3 m³/s pa septembra 2010 (Kovačič, Kolega in Brečko Grubar 2016). Majhna vodnatost Badaševice kaže, tako kot druge reke jadranskega povodja v Sloveniji, negativni trend oziroma zmanjševanje. V dvajsetletnem opazovanem obdobju se srednji letni pretok zmanjšuje za $80 \mathrm{l} / \mathrm{s}$ na desetletje in povprečni letni veliki pretok za 101 /s na desetletje, vendar trenda nista statistično značilna. Statistično značilen pa je padajoči trend povprečnih letnih malih pretokov za 401/s na desetletje (Kovačič 2016). Predvidevamo lahko, da se bo v prihodnje vpliv Badaševice $z$ dotokom sladke vode in sedimentov na lastnosti vode $\mathrm{v}$ Semedelskem zalivu še zmanjševal.

Razrast morskih trav in širjenje travnikov pa bi bil lahko pokazatelj manjše obremenjenosti Badaševice z onesnažili, predvsem s hranili. V preteklosti je bila namreč zelo obremenjena, kar so pokazali rezultati monitoringov kakovosti. »... Visoke vrednosti nitrata in ortofosfata, celokupnega dušika in fosforja smo beležili v reki Badaševici, Rižani in Drnici. Povišane vrednosti detergentov so bile izmerjene v reki Badaševici in Drnici. Spodnji tok rek, ki se izlivajo v morje je tudi fekalno onesnažen, kar potrjujejo rezultati visokih koncentracij koliformnih bakterij fekalnega izvora $(>11.000 / 100 \mathrm{ml})$ v poletnih mesecih v reki Rižani, Dragonji in Badaševici ..." (Turk s sodelavci 2010, 22). Med razlogi za takšno stanje sta bila izpostavljena poselitev in kmetijstvo.

V porečju Badaševice je leta 2011 živelo 9900 prebivalcev, gostota poselitve je bila 251 prebivalcev/ $\mathrm{km}^{2}$, na kanalizacijsko omrežje, povezano s čistilno napravo, pa je bilo priključenih $70 \%$ objektov. Vanganelsko polje in prisojna pobočja na desnem delu porečja so kmetijsko intenzivno izrabljena, kar je bil prav tako ugotovljen vir hranil. Kmetijska raba tal je obsegala nad polovico porečja in na kmetijskih zemljiščih so s $60 \%$ prevladovali vinogradi, intenzivni sadovnjaki, njive in oljčniki, ki so prispevali $89 \%$ obremenitev iz kmetijstva (Poklar in Brečko Grubar 2013). V preteklih letih se je obremenjevanje z odpadnimi vodami precej zmanjšalo, saj je bilo razširjeno kanalizacijsko omrežje in priključenih večina objektov (Podatki ... 2017). Kmetijsko obremenjevanje okolja pa se ni bistveno spremenilo, čeprav smo tudi na tem območju priča zaraščanju. Zaradi tega se je zelo verjetno zmanjšala intenzivnost erozije in odnašanje gradiva iz porečja $\mathrm{v}$ morje.

Vsekakor pa je obdobje spremljanja razširjenosti morskih travnikov prekratko, da bi z gotovostjo potrdili vplive posameznih dejavnikov. Opredelitev procesov in pojasnjevanje časovnih sprememb prostorske porazdelitve morskih travnikov v preučevanem prostoru po naši metodologiji tako še ni mogoče. Za kartiranje razširjenosti morskih travnikov je namreč eno snemanje dovolj, medtem ko mora biti za ugotavljanje sprememb zagotovljena določena porazdelitev izvajanja meritev in kartiranja ter primerno dolgo časovno obdobje. Ustreznost le-te pa je odvisna od vsakokratnih potencialnih vplivov na ekosistem in njegovo kakovostno stanje. V Semedelskem zalivu, ki je v preteklosti veljal za visoko obremenjen 
ekosistem, bi bilo smiselno kartiranje morskih travnikov opraviti vsaj dvakrat letno in to iz več razlogov. Pozimi se zaradi razredčenih poganjkov in listov cimodoceje lahko odlično spremlja porazdelitev leščurjev (Pinna nobilis), ki so, prav tako kot morske trave, indikatorski organizmi za deskriptorje Morske direktive (Direktiva ... 2008). Pozimi je na listih cimodoceje dobro vidna tudi obraščenost $z$ epifiti, katerih močna razrast (predvsem v primeru cianobakterij) je posledica obremenjenosti vode s hranilnimi snovmi oziroma organskega onesnaženja. Poleti je zaradi razrasti cimodoceje bistveno lažje oceniti površine travnikov oziroma nesklenjenih zaplat morske trave. Kolenčasta cimodoceja je izbran indikatorski organizem za deskriptorje Morske direktive pri ocenah biotske raznovrstnosti, neoporečnosti morskega dna, evtrofikaciji ... (Direktiva ... 2008). Poleti je bistveno lažje oceniti tudi prisotnost drugih vrst morske trave, kot sta Zostera marina in Zostera noltii, ter kartirati površine, ki jih poraščajo.

Kljub temu, da je možnih več razširitev oziroma nadgraditev raziskave, predvsem $\mathrm{z}$ daljšim časovnim nizom spremljanja in s pogostejšim kartiranjem morskih travnikov, menimo, da je raziskava pokazala, da uporaba sodobnih tehnologij omogoča nove in za različne stroke uporabne izsledke. Ti pa omogočajo boljše razumevanje procesov, poznavanje stanja v prostoru in njegovih lastnosti. Zavedamo se namreč, da sta dobro poznavanje stanja in razumevanje procesov v prostoru, še posebej v občutljivih okoljih, temelj in hkrati prvi korak $\mathrm{k}$ njegovemu ohranjanju.

\section{Viri in literatura}

Barsanti, M., Delbono, I., Ferretti, O., Peirano, A., Bianchi C. N., Morri, C. 2007: Measuring change of Mediterranean coastal biodiversity: diachronic mapping of the meadow of the seagrass Cymodocea nodosa (Ucria) Ascherson in the Gulf of Tigullio (Ligurian Sea, NW Mediterranean). Hydrobiologia 580-1. DOI: https://doi.org/10.1007/s10750-006-0467-7

Cancemi, G., Buia, M. C., Mazzella, L. 2002: Structure and growth dynamics of Cymodocea nodosa meadows. Scientia Marina 66-4. DOI: https://doi.org/10.3989/scimar.2002.66n4365

Dennison, W. C., Orth, R. J., Moore, K. A., Stevenson, J. C., Carter, V., Kollar, S., Bergstrom, P. W., Batiuk, R. A. 1993: Assessing water quality with submersed aquatic vegetation. BioScience 43-2. DOI: https://doi.org/10.2307/1311969

Duarte, C. M. 2002: The future of seagrass meadows. Environmental Conservation 29-2. DOI: https://doi.org/10.1017/S0376892902000127

Direktiva 2008/56/ES Evropskega parlamenta in Sveta z dne 17. junija 2008 o določitvi okvira za ukrepe Skupnosti na področju politike morskega okolja (Okvirna direktiva o morski strategiji). Uradni list Evropske unije L 164. Luksemburg. Medmeržje: http://eur-lex.europa.eu/legal-content/ SL/TXT/PDF/?uri=CELEX:32008L0056\&from=SL (1.2.2018).

Finkl, C. W., Makowski, C. 2014: Remote sensing and Modeling: Advances in Coastal and Marine Resources. Cham. DOI: https://doi.org/10.1007/978-3-319-06326-3

Johnston, C. A. 1990: GIS: more than just a pretty face. Landscape Ecology 4-1. DOI: https://doi.org/ 10.1007/BF02573946

Krause-Jensen, D., Queresma A. L., Cunha, A. H., Greve, T. M. 2004: How are seagrass distribution and abundance monitored. European Seagrasses: An Introduction to Monitoring and Management. Medmrežje: http://www.seagrasses.org/handbook/european_seagrasses_high.pdf (1.2.2018).

Kovačič, G., Brečko Grubar, V., Kolega, N. 2016: Vpliv podnebnih sprememb na količine vode in poplave morja v slovenski Istri. Geografski vestnik 88-1. DOI: https://doi.org/10.3986/GV88102

Kovačič, G. 2016: Trendi pretokov rek jadranskega povodja v Sloveniji brez Posočja. Geografski vestnik 88-2. DOI: https://doi.org/10.3986/GV88201

Lathrop, R. G., Styles, R. M., Seitzinger, S. P., Bognar, J. A. 2001: Use of GIS mapping and modeling approaches to examine the spatial distribution of seagrasses in Barnegat Bay, New Jersey. Estuaries 24-6A. DOI: https://doi.org/10.2307/1353181 
Lipej, L., Turk, R., Makovec, T. 2006: Ogrožene vrste in habitatni tipi v slovenskem morju. Ljubljana. Malačič, V. 1994: Razvojni projekt občine Koper 2020: varstvo morja in priobalnega pasu. Raziskovalno poročilo, Morska biološka postaja Inštituta za biologijo. Piran.

Moškon, S., Žibert, J., Kavšek, B. 2015: Kartiranje morskih travnikov s podatki mnogosnopnega sonarja. Geografski vestnik 87-1. DOI: https://doi.org/10.3986/GV87106

Orfanidis, S., Papathanasiou, V., Gounaris, S. 2007: Body size descriptor of Cymodocea nodosa indicates anthropogenic stress in coastal ecosystem. Transitional Waters Bulletin 1-2. DOI: https://doi.org/ 10.1285/i1825229Xv1n2p1

Orožen Adamič, M. 2002: Geomorfološke značilnosti Tržaškega zaliva in obrobja. Dela 18. DOI: https://doi.org/10.4312/dela.18.143-155

Oštir, K. 2006: Daljinsko zaznavanje. Ljubljana.

Peterlin, M. (ur.) 2013: Načrt upravljanja morskega okolja: Začetna presoja morskih voda v pristojnosti Republike Slovenije, Bistvene lastnosti in značilnosti morskih voda. Inštitut za vode Republike Slovenije. Ljubljana.

Digitalni model globin. Harpha sea, d. o. o. Koper. Koper, 2008.

Podatki o priključenosti objektov na kanalizacijski sistem v Mestni občini Koper. Marjetica Koper. Koper, 2017.

Poklar, M., Brečko Grubar, V. 2013: Geografska presoja vplivov kmetijstva in poselitve v porečju Badaševice na kakovost morja v Semedelskem zalivu. Geografski vestnik 85-2.

Poklar, M. 2015: Metodologija geografskega raziskovanja stika sladkovodnega in morskega okolja na primeru Semedelskega zaliva. Doktorsko delo, Fakulteta za humanistične študije Univerze na Primorskem. Koper.

Remillard, M. M., Welch, R. A. 1992: GIS technologies for aquatic macrophyte studies: I. Database development and changes in the aquatic environment. Landscape Ecology 7-3. DOI: https://doi.org/ 10.1007/BF00133307

Robbins, B. D. 1996: Quantifying temporal change in seagrass areal coverage: The use of GIS and low resolution aerial photography. Aquatic Botany 58, 3-4. DOI: https://doi.org/10.1016/S0304-3770(97)00039-9

Soczka Mandac, R., Bogunović, B., Žagar, D., Faganeli, J. 2014: Riverine impact on the thermohaline properties, turbidity and suspended solids in a shallow bay (Bay of Koper, northern Adriatic Sea). Acta Adriatica 55-2.

Soczka Mandac, R., Faganeli, J. 2015: Deposition of riverine suspended solids in a shallow bay (Bay of Koper, Gulf of Trieste, northern Adriatic Sea). Journal of Soils and Sediments 15-12. DOI: https://doi.org/10.1007/s11368-015-1146-y

Steinman, F., Gosar, L., Rajar, R., Kompare, B., Banovec, P., Pogačnik, N. 2004: Strokovne podlage za lokacijski načrt »Marina in komunalni privezi« v Kopru: maritimna študija. Končno poročilo, Fakulteta za gradbeništvo in geodezijo Univerze v Ljubljani. Ljubljana.

Telesca, L., Belluscio, A., Criscoli, A., Ardizzone, G., Apostolaki, E. T., Fraschetti, S., Gristina, M., Knittweis, L., Martin, C. S., Pergent, G., Alagna, A., Badalamenti, F., Garofalo, G., Gerakaris, V., Pace, M. L., Pergent-Martini, C., Salomidi, M. 2015: Seagrass meadows (Posidonia oceanica) distribution and trajectories of change. Scientific Reports 5. DOI: https://doi.org/10.1038/srep12505

Turk, V., Bajt, I., Mozetič, P., Poje, M., Ramšak, A., Šiško, M., Malej, A. 2010: Program spremljanja kakovosti morja in vnosov onesnaženja s kopnega v skladu z Barcelonsko konvencijo v letu 2010. Agencija Republike Slovenije za okolje. Ljubljana. Medmrežje: http://www.arso.gov.si/vode/morje/Barcelonska_2010.pdf (1.2.2018).

Virnstein, R., Avery, W. M., Johansson, R. O. 2000: On defining the »edge« of a seagrass bed. Reports 145. Medmrežje: https://scholarcommons.usf.edu/basgp_report/145 (1.2.2018). 


\section{Summary: The changes of seagrass meadows on the Semedela Bay seabed in period 2009-2015}

(translated by Branka Klemenc)

The paper presents the results of the research in order to establish chronological changes in the seagrass cover of the Semedela Bay seabed. The research focused on the $0.43 \mathrm{~km}^{2}$ large area of the Koper Bay between Žusterna and the old city core, where the river Badaševica flows into the sea. The shallow silt seabed is covered with the plant families of the so-called little Neptune grass (Cymodocea nodosa) and common eelgrass (Zostera marina). In the past, the area was regarded as environmentally badly burdened due to discharges of untreated waste waters into the sea and because of polluters and sediments brought to the Bay by the Badaševica. Conditions for seagrass growth were limited because the seawater was cloudy and polluted. We tried to find out the changes that took place in the recent years after the draining off and treatment of waste waters in the Municipality of Koper had been ameliorated, and to what extent the impact of the Badaševica outfall was still evident.

With regard to the thickness and extent of the seagrass cover, we defined three types of seabed in the Semedela Bay: barren seabed, patches of seagrass of less than 0.1 ha, and marine meadows with more than 0.1 ha of continuous vegetation. Then followed the mapping and drawing of cartographic presentations of the range of seagrasses. The data were acquired by means of two methods of remote sensing, that is by sonar mapping and aerial photography. With the help of multibeam echosounder precise bathymetric measurements of the Semedela Bay were also performed, which served for the construction of a digital bathymetric model. The latter then served as a basis for mapping sea meadows. Aerial photography provided images which were first joined into an overall photograph of the entire research area, and then it was orthorectified and georeferenced. This ortophotograph was then used for digitalizing the marine meadows. Both methods of remote sensing were verified by the method of linear transects and central points of marine meadows when we checked their state by means of underwater photography along individual transects or at central points, respectively.

The first presentation of the types of seagrass bed was made for the year 2009; the procedure of acquiring and processing the data was repeated for the years 2011, 2013 and 2015. The paper presents the situation in the year 2015, when $39.1 \%$ of the seabed was barren, $15.4 \%$ was covered with discontinuous patches of seagrass, and the remaining parts were covered with marine meadows. There are two major marine meadows in the Semedela Bay as well as a number of minor ones. One of the two major meadows is situated on the eastern side where it spreads from the Semedelska cesta street towards the north-west. It reaches from the depth of $0.3 \mathrm{~m}$ by the coast to the depth of $5.26 \mathrm{~m}$ further on and extends over 12.20 ha. It consists of common eelgrass (Zostera marina) and little Neptune grass (Cymodocea nodosa). The second larger marine meadow consists of Cymodocea nodosa and lies in the western part where it spreads along the Istrska cesta street from Žusterna towards the outfall of the Badaševica. It is about 5.89 ha large, and reaches the deepest point at $5 \mathrm{~m}$ in the north-westernmost part. By analysing the situation in individual years, we got an insight into the chronological-spatial changes of marine meadows covering the seabed in the 2009-2015 period. In the year 2009, the percentage of seabed that was covered with marine meadows amounted to $25.7 \%$, by the year 2013 it increased to $33.5 \%$, and by the year 2015 to $45.5 \%$. The total area of marine meadows in the studied period thus increased by 8.57 ha or by $44 \%$; the greatest increase occurred in the final, i.e. 2013-2015, period when it increased as much as by 5.20 ha.

Our analysis also showed the degree and direction of the spread or reduction of the two meadows, or where their outer borders moved. The results show that the lower borders of both meadows sunk and reached noticeably deeper in 2015 than in 2009. Since both types of the prevailing seagrasses (Cymodocea nodosa and Zostera marina) are sensitive to the increased cloudiness of seawater, which is greatly responsible for their shrinking on a global scale, the spread of marine meadows to a deeper seabed could indicate lesser cloudiness of water in the Semedela Bay. The reasons for the latter issue could be found 
in the stabilizing, or connectedness, of the sediment and in the lesser undulation as the main reason of raising the sediment. The reason may also lie in decreased transport of sediments by the waters of the Badaševica river. In the past, the Badaševica supplied polluted waters rich in nutrient matter to the Bay, which was the possible reason of the extremely impoverished vegetation at its mouth area. The two types of seagrass, the little Neptune grass and the common eelgrass, are both sensitive also to increased nutrient content. The spread of marine meadows towards the outfall of the Badaševica, which is strongly expressed mainly in the latest period of monitoring, i.e. 2013-2015, proves just the opposite: that the Badaševica no longer exerts a negative impact on the growth of seagrass and the ecological state of the Semedela Bay. This had also been shown by spatial analysis of monitored indicators of water properties in a prior research (Poklar 2015). It is also necessary to know that the Badaševica brings relatively small amounts of fresh water into the Semedela Bay (the average annual flow in the 1994-2013 period amounted to $0.24 \mathrm{~m}^{3} / \mathrm{s}$ ), and they have been even decreasing in the recent period.

The period of monitoring the change in extent of marine meadows is certainly too short to enable reliable conclusions on the impacts of individual factors. It is still not possible to define the processes and explain chronological changes in spatial distribution of marine meadows in the researched area by means of our methodology. A single mapping is sufficient to get a map of the extent of marine meadows, whereas to establish the changes requires a certain sequence of performed measurements and mappings. The accuracy of these actually depends on the possible impacts on the ecosystem and its state of quality. It would be reasonable to carry out the mapping of marine meadows in the Semedela Bay at least twice a year for several reasons. Thanks to thinner shoots and leaves of the Cymodocea nodosa in wintertime, it is possible to excellently monitor the distribution of Noble pen shell (Pinna nobilis), which are, like seagrass, indicator organisms for the descriptors of the EU Marine Strategy Framework Directive (2008). In wintertime it is also well visible how the leaves of the Cymodocea are overgrown with epiphytes whose lush growth (especially in the case of cyanobacteria) results from the burdening of water with nutrient matter or organic pollution. Thanks to the abundant growth of the Cymodocea in summertime, it is by far easier to assess the area of marine meadows or discontinuous patches of seagrass and establish the presence of other sorts of seagrass, such as Zostera marina and Zostera nol$t i i$, and map the areas overgrown with them. Even though we are aware that the present research can be extended, or upgraded, in several aspects, we believe that the results have shown that the use of modern technologies paves the way for new findings, useful for different disciplines. These findings will render possible better understanding of processes and better spatial knowledge. It is clear to us that good knowledge and understanding of spatial processes, especially in sensitive environments, is the basis of and the first step to its conservation. 